$\begin{array}{r}\text { Volume and Issues Obtainable at Center for Sustainability Research and Consultancy } \\ \text { Journal of Accounting and Finance in Emerging Economies } \\ \text { ISSN: 2519-0318 ISSN (E) 2518-8488 } \\ \text { Volume 3: Issue 2 December 2017 } \\ \text { JSRᄃ } \\ \text { Journal homepage: www.publishing.globalcsrc.org/jafee } \\ \hline\end{array}$

\title{
Relationship between Situational Inhibitors and Informal Learning amongst Accountants
}

\section{${ }^{1}$ Muhammad Syahir Abdul Wahab, ${ }^{2}$ Mohamad HisyamSelamat, ${ }^{3}$ Ram Al-JaffriSaad, ${ }^{4}$ Mohd. Amir MatSamsudin}

${ }^{1,3,4}$ TunkuPuteriIntanSafinaz School of Accountancy, Universiti Utara Malaysia, 06010 UUM Sintok, Kedah DarulAman, Malaysia.

${ }^{2}$ SEGi University, Faculty of Business, Accounting and Management, 47810 Petaling Jaya, Selangor Darul Ehsan, Malaysia.

\begin{tabular}{|c|c|}
\hline ARTICLEDETAILS & ABSTRACT \\
\hline History & Purpose: Informal learning activities are important for chartered \\
\hline Revised format: Nov 2017 & accountants in public accounting firms to develop and maintain knowledge \\
\hline Available online: Dec 2017 & and skills within the professional environment. However, recent evidence \\
\hline Keywords & $\begin{array}{l}\text { indicates that situational inhibitors to the learning exist in their working } \\
\text { environment. Thus, the objective of this research is to examine the }\end{array}$ \\
\hline Accountant, & relationship between situational inhibitors and informal learning activities \\
\hline Continuing Professional, & amongst the accountants. \\
\hline Education, & Design/Methodology/Approach: A total of 260 chartered accountants in \\
\hline Informal Learning, & the firms across Malaysia participated in this study. The data of the study \\
\hline $\begin{array}{l}\text { Situational Inhibitors, } \\
\text { Survey }\end{array}$ & $\begin{array}{l}\text { was collected through mail survey approach and analysed using correlation } \\
\text { analysis. }\end{array}$ \\
\hline & Findings: The findings indicated that lack of time and lack of support from \\
\hline $\begin{array}{l}\text { JEL Classification: } \\
C 42, D 83\end{array}$ & $\begin{array}{l}\text { others inhibited the accountants' informal workplace learning activities. The } \\
\text { evidence suggests that accountants who face these two constraints at the } \\
\text { workplace, would be less likely to engage in informal learning activities. } \\
\text { Implications/Originality/Value: This study adds to previous literature by } \\
\text { testing the relationship between situational inhibitors and the accountants' } \\
\text { informal learning activities. Practically, the research findings are critical for } \\
\text { accounting profession in developing appropriate strategies to overcome the } \\
\text { identified problems. }\end{array}$ \\
\hline
\end{tabular}

(C) 2017 The authors, under a Creative Commons Attribution-

NonCommercial 4.0

Corresponding author's email address: syahir@uum.edu.my

Recommended citation:Wahab,M.S.A., Selamat,M.H.S., Saad,R.A.J. \&Samsudin, M.A.M., (2017).Relationship between Situational Inhibitors and Informal Learning amongst Accountants.Journal of Accounting and Finance in Emerging Economies, 3(2) 179-185.DOI: https://doi.org/10.26710/jafee.v3i2.78

\section{Introduction}

Over the last decades, corporate strategy and organizational learning studies have discovered that workplace learning is the foundation for the organizations to sustain competitiveness in a rapidly transforming economic environment (Alfonso, 2017; Sambrook, 2005; Senge, 1990). Although workplace learning can be categorized into formal (for instances, courses, seminars and conferences) and informal (for examples, reading, knowledge sharing and discussion) (Cofer, 2000), much of learning in the 
organizations occurs through informal means (Alfonso, 2017; Eraut, 2004; Clifford \& Thorpe, 2007; Marsick, 2009; Rothwell, 2003). According to Billett and Choy (2013), and Kim and McLean (2014), this trend also indicates that formal learning is no longer sufficient for continuous knowledge and skills development amongst professionals.

Informal learning related issues have been studied amongst various professionals such as school leaders (Veelen, Sleegers, \&Endedijk, 2017),nurses (Bjørk, Tøien, \&Sørensen, 2013), human resource management practitioners (Crouse, Doyle, \& Young, 2011), teachers(Bakkenes, Vermunt, \&Wubbels, 2010;Lohman, 2009), managers (Ashton, 2004; Billett, 2003) and accountants (Abdul Wahab, Selamat, \& Saad, 2012; Hicks, Bagg, Doyle, \& Young, 2007). The focus of this research is on accountants in public accounting firms since the learning is mandatory for their professional development (Hicks et al., 2007; Malaysian Institute of Accountants (MIA), 2014).

Although the learning is important for the accountants, Audit Oversight Board Malaysia (AOB) (2010, 2011, 2013) indicated that situational inhibitors exist in their working environment. Prior studies have highlighted the inhibitors, however, empirical evidence on the relationship between the learning activities and the inhibitors is still limited (Abdul Wahab, Saad, \& Selamat, 2014). Therefore, this research aims to examine such relationship amongst the accountants.

This study has the following structure. Section 2 reviews the relevant literature related to objective of this research. In Section 3, research hypotheses are developed while research method is described in Section 4. Section 5 discusses the research findings. Thereafter, the conclusion and implications for theory, practice and research are also provided.

\section{Literature Review}

In accounting profession, workplace learning is known as Continuing Professional Education (CPE) (MIA, 2011). The learning is important for accountant to keep abreast of current and future developments in accounting practices (International Federation of Accountants (IFAC), 2008; MIA 2011). The CPE has two categories, namely, formal and informal. Education that is systematic, structured and formal in nature is the formal learning in the profession (IFAC, 2008). Examples of formal learning are attendance to seminars, workshops, conferences and post-graduate studies (MIA, 2011). Meanwhile, informal learning refers to unstructured learning that related to accountants' works such as accounting and auditing matters (MIA, 2011). The activities are reading, use of audio or video, correspondence courses, meeting, briefing session and group discussion (MIA, 2011). Since this study focuses on informal learning of the accountants, the above six activities are then selected.

Lohman (2000), by following Cross (1981), suggested that situational inhibitors represent circumstantial conditions that reduce the ability of employees to pursue informal learning activities. Thus, situational inhibitors in this study refer to circumstantial conditions in public accounting firms that reduce the ability of accountants to engage in informal learning activities.

\section{Hypotheses Development}

This section discusses the hypotheses of this study. The description of hypothesis for each situational inhibitor to informal learning is dealt with in the following sub-sections:

\subsection{Lack of Time}

Professionals spend most of their office hours to accomplish work tasks (Merriam et al., 2007). Thus, time is frequently cited as the reason for less informal learning activities (Merriam et al., 2007). Prior research found that the greater time constraint experienced at the workplace, the lower engagement in informal learning activities (Hicks et al., 2007; Tannenbaum, 1997). This relationship is also consistent 
with other scholars such as Crouse et al. (2011), Ellinger and Cseh (2007), Ellstrom et al. (2008) and Lohman (2000, 2005, 2006, 2009). Thus, it is contended that an accountant who faces this constraint at the workplace, would be less likely to participate in informal learning activities. Consistent with the above discussion, the hypothesis is:

H1: There is a negative relationship between lack of time and informal learning activities amongst the accountants

\subsection{Lack of Proximity to Colleagues' Working Areas}

Macneil (2001) argued that physical location between workers at the workplace can limit informal learning activities. Prior studies found that when colleagues in the same division or department are not located near to each other, they are less likely to engage in informal learning activities (Lohman 2000, 2005, 2006, 2009; Lohman \& Woolf, 2001). Therefore, it is argued that an accountant who is not located near to his or her colleagues' working areas would be less likely to learn informally from each other. Thus, the proposed hypothesis is:

H2: There is a negative relationship between lack of proximity to colleagues' working areasand informal learning activities amongst the accountants

\subsection{Lack of support from others}

The unwillingness of knowledgeable colleagues to support informal learning activities causes other employees feel helpless and directionless (Lohman, 2005, 2009; Marsick\& Watkins, 1990). Previous studies indicated that lack of support from others was associated with less informal learning activities at the workplace (Ellstrom et al., 2008; Lohman, 2009; Tannenbaum, 1997). Other studies such as Ashton (2004), Hicks et al. (2007) and Jurasaite-Harbison (2009) also reported the similar influence of this problem on informal learning activities. Thus, it is argued that an accountant, who receives limited support from knowledgeable colleagues, would be less likely to involve in informal learning activities. The hypothesis is as follows:

H3: There is a negative relationship between lack of support from others andinformal learning activities amongst the accountants

\subsection{Structural Inhibitor}

Physical separation between units or department at the workplace creates obstacles to informal learning activities amongst employees (Ellinger\&Cseh, 2007; Jurasaite-Harbison, 2009). Prior studies found that this problem was associated with less informal activities (Ellinger\&Cseh, 2007; Jurasaite-Harbison, 2009). Therefore, it is suggested that separation between units or departments in accounting firms would lead to limited informal learning opportunities amongst the accountants. Hence, the proposed hypothesis is:

H4: There is a negative relationship between structural inhibitor and informal learning activities amongst the accountants

\section{Research Method}

Respondents of this research are MIA members in the firms across Malaysia. The chartered accountants were selected as the learning is mandatory to keep abreast with changes that affect their professional works (MIA, 2011). The MIA membership database was used to select research respondents. There were 6,513 active members in the firms throughout the country (MIA, 2011). Six hundred sixty members (approximately $10 \%$ of the population) were randomly selected from the database. The questionnaires were mailed to their correspondence addresses. Out of 660 distributed questionnaires, 260 questionnaires 
were returned, producing a response rate of 39.4 percent. A response rate of 30 percent is considered appropriate for mail survey research (Sekaran, 2003). Thus, the response rate of this research was considered acceptable.

The respondents were asked to rate the frequency of engagement in six informal learning activities. They were also asked to rate the agreement on the extent to which four situational factors inhibit their informal learning activities. Likert scales, ranging from 1 to 7 , were used for all learning activities and situational inhibitors items (see APPENDIX A). Correlation analyses were used to analyse the research data (Pallant, 2010).

\section{Findings}

A correlation analysis examined the relationship between the situational inhibitors and informal learning activities. Data testing to meet assumptions of normality, linearity and homoscedasticity were performed prior to research data analysis (Pallant, 2010). In addition, none of the variables of this research demonstrated below the minimum reliability level $(<0.60)$ (Hair et al., 2006). The following Table shows the research findings.

\section{Table 1: Correlations between Informal Learning Activities and Four Situational Inhibitors (N=260)}

\begin{tabular}{llllll}
\hline & ILA & LOT & LOP & LOS & STI \\
\hline ILA & 1 & & & & \\
LOT & $-.408^{* *}$ & 1 & & & \\
LOP & -.088 & .033 & 1 & & \\
LOS & $-.409^{* *}$ & $.305^{* *}$ & $.269^{* *}$ & 1 & \\
STI & -.119 & -.062 & $-.129^{*}$ & .032 & 1 \\
\hline$* * p<.001$ (2-tailed). & & & & &
\end{tabular}

As can be seen in Table 1, a significantly moderate negative correlation was found between informal learning activities and lack of time (LOT) $(r=-.408, p=0.000)$. There was also a significant moderate negative correlation between the learning activities (ILA) and lack of support from others (LOS) $(r=-$ $.409, p=0.000$ ) (Cohen, 1988). These two correlations indicate that as the perceived strength of each situational inhibitor increases, the frequency of the learning activities decreases (Lohman, 2009). The analysis also revealed insignificant low negative correlations between informal learning activities (ILA) and lack of proximity to colleagues' working areas (LOP) $(r=-.088, p=.159)$, and structural inhibitor (STI) $(r=-.119, p=.057)$ (Cohen, 1988). This means that these two factors were less likely to inhibit their informal learning activities. Thus, it can be concluded that two research hypotheses $(H 1$ and $H 3)$ were supported while other two were not supported ( $\mathrm{H} 2$ and $H 4)$.

\section{Conclusions and Implications}

This research examined the relationship between situational inhibitors and informal learning activities amongst the accountants. The research findings indicated that lack of time andlack of support from others were the situational inhibitors. Prior studies consistently reported that these two factors made professionals' informal learning difficult (Ashton, 2004; Hicks et al., 2007; Lohman, 2006, 2009). The results also showed that lack of proximity to colleagues' working areas and structural inhibitor were not perceived by the accountants as the inhibitors (Hicks et al., 2007).

This study contributes towards theory by providing empirical evidence on the relationship between situational inhibitors and the accountants' informal learning activities. In terms of practical aspect, the research findings are critical for accounting profession in developing appropriate strategies to overcome the identified problems. 
This study employed correlation analysis to examine the relationship between informal learning activities and the situational inhibitors. Further research could test the relationship using other statistical approaches such as multiple regression analysis since it has more ability to predict a particular outcome compared to correlation analysis (Pallant, 2010).

\section{References}

Abdul Wahab, M. S., Selamat, M. H., \& Saad, R. A. (2012). Work environment inhibitors to informal workplace learning activities amongst accountants: A Malaysian case study. Paper presented at the Qualitative Research Conference, Kuala Lumpur, Malaysia. (6-7 November 2012).

Abdul Wahab, M. S., Saad, R. A., \& Selamat, M. H (2014).A survey of work environment inhibitors to informal workplace learning activities amongst Malaysian accountants. Paper presented at the International Conference on Accounting Studies, Kuala Lumpur, Malaysia. (18-19 August 2014)

Alfonso J. G. M. M. (2017). Learning opportunities for group learning: an empirical assessment from the learning organization perspective.Journal of Workplace Learning, 29(1), 1 -33.

Ashton, D. N. (2004). The impact of organizational structures and practices on learning in the workplace.International Journal of Training and Development, 8(1), 43-53.

Audit Oversight Board Malaysia (2010). Annual Report 2010. Retrieved from http://www.sc.com.my/wpcontent/uploads/eng/html/aob/ar2010/aob_ar2010_eng.pdf

Audit Oversight Board Malaysia (2011). Annual Report 2011. Retrieved from http://www.sc.com.my/wpcontent/uploads/eng/html/aob/ar2011/aob_ar2011_eng.pdf

Audit Oversight Board Malaysia (2013). Annual Report 2013. Retrieved from http://www.sc.com.my/wpcontent/uploads/eng/html/aob/ar2013/aob_ar2013_eng.pdf

Bakkenes, I., Vermunt, J. D., \&Wubbels, T. (2010). Teacher learning in the context of educational innovation: Learning activities and learning outcomes of experienced teachers. Learning and Instruction, 20, 533-548.

Billett, S. (2003). Workplace mentors: Demands and benefits. Journal of Workplace Learning, 15(3), 105-113.

Billett, S., \& Choy, S. (2013). Learning through work: emerging perspectives and new challenges. Journal of Workplace Learning, 25(4), 264-276.

Bjørk, I. T., Tøien, M., \&Sørensen, A. L. (2013).Exploring informal learning among hospital nurses.Journal of Workplace Learning 25(7), 426-440.

Clifford, J., \& Thorpe, S. (2007). Workplace learning and development: Delivery competitive advantage for your organization. Philadelphia: Kogan Page Limited.

Cofer, D. A. (2000).Informal Workplace Learning(Practical Application Brief No. 10). Columbus, OH: Center of Education and Training for Employment.

Cohen, J. W. (1988). Statistical power analysis for the behavioral sciences $\left(2^{\text {nd }}\right.$ ed.). Hillsdale: Lawrence Erlbaum Associates.

Cross, K. P. (1981). Adults as learners: Increasing participation and facilitating learning. San Francisco: Jossey-Bass.

Crouse P., Doyle, W. \& Young, J. D. (2011). Workplace learning strategies, barriers, facilitators and outcomes: A qualitative study among human resource management practitioners. Human Resource Development International, 14(1), 39-55.

Ellinger, A. D., \&Cseh, M. (2007). Contextual factors influencing the facilitation of others' learning through everyday work experiences, Journal of Workplace Learning, 19(7), 435-452.

Ellstrom, E., Ekholm, B., \&Ellstrom, P. (2008). Two types of learning environment: Enabling and constraining a study of care work. Journal of Workplace Learning, 20(2), 84-97.

Eraut, M. (2004).Informal learning in the workplace.Studies in Continuing Education, 26(2), 247-273.

Hair, J. F., Black, W. C., Babin, B. J., Anderson, R. E., \& Tatham, R. L. (2006).Multivariate data analysis $\left(6^{\text {th }} e d\right.$.). New Jersey: Pearson International Edition.

Hicks, E., Bagg, R., Doyle, W., \& Young, J. D. (2007). Canadian accountants: Examining workplace 
learning. Journal of Workplace Learning, 19(2), 61-77

International Federation of Accountants (2008). International Education Standards 1-8. Retrieved from http://www.ifac.org./Members/DownLoads/pdf

Jurasaite-Harbison, E. (2009). Teachers' workplace learning within informal contexts of school cultures in the United States and Lithuania. Journal of Workplace Learning, 21(4), 299-321.

Kim, S., \& McLean, G. N. (2014). The impact of national culture on informal learning in the workplace.Adult Education Quarterly, 64(1), 39-59.

Lohman, M. C. (2000). Environmental inhibitors to informal learning in the workplace: A case study of public school teachers, Adult Education Quarterly, 52(2), 83-101.

Lohman, M. C. (2005). A survey of factors influencing the engagement of two professional groups in informal workplace learning activities.Human Resource Development Quarterly, 16(4), 501-527.

Lohman, M. C. (2006). Factors influencing teachers' engagement in informal learning activities.Journal of Workplace Learning, 18(3), 141-156.

Lohman, M. C. (2009). A survey of factors influencing the engagement of information technology professionals in informal workplace learning activities.Information Technology, Learning and Performance Journal, 25(1), 43-52.

Lohman, M. C., \& Woolf, N. H. (2001).Self-initiated learning activities of experienced public school teachers: Methods, sources, and relevant organizational influences.Teachers and Teaching: Theory and Practice, 7(1), 61-76.

Macneil, C. (2001). The supervisor as a facilitator of informal learning in team works. Journal of Workplace Learning, 13(6), 246-253.

Malaysian Institute of Accountants (2011).By-Laws (On Professional Conduct and Ethics) of the Malaysian Instituteof Accountants. Retrieved from http://www.mia.org.my/handbook/bylaws_new /ByLaws\%20(Revised\%20Jan\%202011)\%20updated\%20as\%20at\%2029\%20January\%202015.pdf

Malaysian Institute of Accountants (2014).Annual Report 2014. Retrieved from http://www.mia.org.my/ar/2014/downloads/MalaysianInstituteofAccountantsAnnualReport2014.pdf

Marsick, V., J. (2009). Toward a unifying framework to support informal learning theory, research and practice.Journal of Workplace Learning, 21(4), 265-275

Pallant, J. (2010). Survival manual: A step by step guide to data analysis using SPSS (4 $4^{\text {th }}$ ed.). New York: McGraw-Hill.

Rothwell, W. (2003). What CEOs expect from corporate training: Building workplace learning and performance initiatives that advance. New York:AMACOM.

Sambrook, S. (2005).Factors influencing the context and process of work-related learning.Human Resources Development International, 8(1), 101-119.

Sekaran, U. (2003). Research method for business: A skill building approach (4 ${ }^{\text {th }}$ Ed.). Danvers, MA: John Wiley \& Sons.

Senge, P. (1990). The fifth discipline: The art and practice of learning organizations. New York: Doubleday.

Tannenbaum, S. I. (1997). Enhancing continuous learning: Diagnostic finding from multiple companies.Human Resource Management, 36(4), 437-452.

Veelen,R. v., Sleegers,P. J. C., \&Endedijk, M. D. (2017),Professional learning among school leaders in secondary education: The impact of personal and work context factors. Educational Administration Quarterly, 1-44. 


\section{APPENDIX A}

Items Constituting the Engagement in Informal Learning Activities Scale

How frequently do you engage in the following informal learning activities at the workplace to develop and maintain knowledge and skills as a chartered accountant?

1. Reading job related materials

2. Using audio/video

3. Participating in discussion group

4. Participating in meeting

5. Participating in briefing session

6. Using correspondence courses (e.g. distance learning)

Items Constituting the Lack of Time Scale

1. Having too many jobs to do makes informal learning difficult for me

2. I have limited time to learn informally about my job

3. I have problem in getting time off for informal learning due to heavy workload

4. Time for informal learning is insufficient

5. Time to spend on informal learning is restricted by heavy workload

Items Constituting the Lack of Proximity to Colleagues' Working Areas Scale

1. I feel physically separated from my colleagues at work

2. I feel difficult to interact with my colleagues since they are at different places

3. I am far away from my colleagues who can support my informal learning

4. Physical arrangement at my office provides few opportunities to learn from my colleagues

5. There are few informal learning opportunities due to physical distance

Items Constituting the Lack of Support from OthersScale

1. At my firm, knowledgeable colleagues offer little guidance for informal learning

2. At my firm, knowledgeable colleagues provide few informal learning opportunities

3. At my firm, knowledgeable colleagues reluctant to support my informal learning

4. I find it difficult to get someone in my firm to coach me

5. I feel difficult to get informal learning opportunities from knowledgeable colleagues in the firm

6. At my firm, knowledgeable colleagues hesitate to share their knowledge with me

Items Constituting the Structural InhibitorScale

1. I have little knowledge on how my job relates to other units/departments

2. I lack of knowledge about the work activities of other units/departments

3. I feel difficult to be close with staff members from other units/departments

4. My office building (e.g. different floors/buildings) provides few opportunities to interact between units/departments 